medRxiv preprint doi: https://doi.org/10.1101/2020.09.28.20203067; this version posted September 29, 2020. The copyright holder for this preprint (which was not certified by peer review) is the author/funder, who has granted medRxiv a license to display the preprint in perpetuity.

It is made available under a CC-BY-ND 4.0 International license .

\title{
Heat-based N95 mask decontamination and reuse in a large hospital setting
}

\author{
Tushar Vora*, Arnab Bhattacharya**, Shankar Ghosh**, Kiran Gowda*, Nandita Dhanaki*, Rajul \\ Gala*, Nitin Dubey*, Vandana Raut*, Vikas Kumar Singh*, Gagan Prakash*, Sarbani Ghosh Laskar*, \\ Manju Sengar*, Girish Chinnaswamy*, C S Pramesh* \\ *Tata Memorial Hospital/Homi Bhabha National Institute, Tata Memorial Centre, Ernest Borges \\ Road, Mumbai 400012, India \\ **Tata Institute of Fundamental Research/Homi Bhabha National Institute, Homi Bhabha Road, \\ Mumbai 400005, India
}

The first two authors contributed equally to this work

Key words: COVID-19, decontamination, N95 masks

Address for correspondence-prameshcs@tmc.gov.in

Dr. C S Pramesh

Director, Tata Memorial Hospital

Ernest Borges Road, Mumbai

India-400012 


\begin{abstract}
The shortage of N95 masks have spurred efforts on developing safe and scientifically-validated decontamination and reuse protocols that are easily scalable and universally applicable even in lowresource settings. We report on the development and implementation of a heat-based N95 mask decontamination system in a large hospital setting (Tata Memorial Hospital, Mumbai, India) with over 8000 N95 masks from about 1400 individual users decontaminated and in reuse till date. We describe the challenges and constraints in choosing a proven, scalable, and easy-to-implement decontamination solution. We discuss the heat treatment and particle filtration efficiency measurement experiments done to validate a decontamination treatment protocol at a target temperature of $70^{\circ} \mathrm{C}$ for a duration of 60 minutes, and the scaling up of this method using a standard hot drying cabinet at the hospital. The logistics of ensuring optimal utilization of the decontamination facility without compromising on basic safety principles are detailed. Our method relies on equipment available in standard hospitals, is simple to set-up, scalable, and can be easily replicated in low-resource settings. We further believe such limited reuse strategies, even in times of abundant N95 mask availability, would not only be cost-saving but also be environmentally responsible in reducing the amount of medical waste.
\end{abstract}




\section{Introduction}

The use of face masks by health care workers and the public has been universally recognized as a key non-pharmaceutical Intervention in controlling the current COVID-19 pandemic ${ }^{1}$. Filtering facepiece respirator (FFR) masks meeting the N95 (or FFP2) specification are a vital part of personal protective equipment for health care workers. N95 FFRs have traditionally been single-use items typically disposed after short term usage to avoid risk of infection and cross contamination; however, the unprecedented shortages of these masks spurred global efforts at developing scientifically-validated and reproducible methods for N95 decontamination and re-use. ${ }^{2-5}$ Several decontamination methods have been proposed including ultraviolet UV-C irradiation ${ }^{4,6-8}$, microwave oven use ${ }^{6}$, autoclaving and moist/dry heat treatment ${ }^{4,8-14,15}$, and chemical usage (e.g. ethylene oxide ${ }^{6,16}$, hydrogen peroxide vapour ${ }^{6,7}$, chloride dioxide ${ }^{17}$, bleach $^{6,16}$, ethanol $\left.{ }^{7,15}\right)$. However, these need to meet not only stringent criteria for viricidal efficacy, ${ }^{18,19}$ but should also not affect the particle filtration efficiency and fit of the mask, ${ }^{20}$ and not leave chemical residues. Most importantly, the method should be easily implementable on a hospital scale, and ideally be usable even in remote and/or low-resource settings. While several studies have evaluated such decontamination methods, they are primarily laboratory demonstrations of possible protocols, with very few published reports on large-scale hospital implementations. Czubryt et al. recently reported ${ }^{21}$ a heat-based decontamination study with a cohort of only 14 N95 respirator samples. In this report, we document the development and implementation of a heat-based N95 decontamination system at a large hospital (Tata Memorial Hospital (TMH), Mumbai) with over 8000 N95 masks decontaminated and in reuse till date.

\section{Tata Memorial Centre / Hospital, COVID-19 and N95 masks}

Tata Memorial Centre / Hospital (TMC/TMH) is the oldest and largest comprehensive cancer care centre in India. Located in Mumbai, TMH registers more than 75,000 new patients with cancer each year, with the majority coming from distant places. Early on, in March 2020, when the implications of COVID-19 pandemic were beginning to be felt worldwide, a conscious decision was taken by TMC to continue and not compromise cancer care (albeit with extensive adaptive modifications), lest the long-term consequences be much more devastating, and also take care of patients and staff who would invariably, at some point, be exposed to and acquire COVID-19 illness. The details of various strategies employed to fulfil our goal to continue care of cancer with COVID-19 have been reported earlier. ${ }^{22}$ To cater to the need of $\sim 1500$ staff requiring N95 mask usage we anticipated a demand/supply mismatch and started collaborative efforts with Tata Institute of Fundamental Research (TIFR) for optimal selection of N95 masks and developing methods for decontamination and reuse in March 2020 itself. 


\section{Selection of Method for N95 Mask Decontamination and Reuse}

We selected the most appropriate, effective and pragmatic method for decontamination of N95 masks on a large scale based on five criteria: 1. Proven viricidal efficacy, 2. No degradation of mask filtration efficacy, 3. Preservation of mask structural integrity and face fit, 4. Lack of chemical residues, and 5. Ease of logistical implementation in a large hospital setting. For the last point, our challenges were not only the large numbers of masks but also the safety of the personnel who carried out the decontamination, and simplicity of returning the decontaminated mask to the same user, in a timely manner. The practical issues in setting up a decontamination system became even more important as India, and Mumbai in particular, went under a very strict lockdown from the end of March, severely constraining the availability of equipment and manpower.

Of the reported decontamination techniques, a review of prior literature and technical summaries published by N95decon consortium (www.n95decon.org), suggested that the suitable methods for our purpose were UV-C irradiation, hydrogen peroxide vapour treatment, and heat-based techniques. Chemical disinfection methods were deemed risky due to residues or uncertain impact on filtration efficiency. Simple procedures like treatment with dilute bleach or alcohol-based solutions would not be acceptable since they remove the electrostatic charge on N95 mask filter media and degrade filtration efficiency. ${ }^{23}$ Implementation of UV-C methods was fraught with difficulties like elimination of shadows, providing uniform illumination of sufficient intensity and most importantly, availability of UV-C germicidal lamps during the lockdown. Large hydrogen peroxide vapour based commercial systems (e.g. the Battelle ${ }^{24}$ or Steris ${ }^{25}$ decontamination systems) were not available in India. Heat-based decontamination methods were hence felt to be most suitable due to easy applicability, availability and accessibility at a fraction of the cost as compared to other methods. With availability of autoclaves and hot drying cabinets in almost all hospital settings, we felt that successful demonstration of this method would make it easier to replicate in similar scenarios.

Heat-based inactivation of pathogens via autoclaving is a standard sterilization method used in hospitals world over. However, some N95 masks have failed fit tests after even one standard autoclave cycle. ${ }^{1313} \mathrm{~A}$ careful control of temperature, humidity, and decontamination time is required to achieve viral inactivation while maintaining N95 filter performance. Further, the decontamination conditions effective for mask filtration media surfaces may vary from those used in studies on standard media used in experimental conditions. Recent studies have shown that the SARS-COV-2 virus can be inactivated by exposure to temperatures of $70^{\circ} \mathrm{C}$ for $30-60$ minutes depending on the ambient humidity. A heat-treatment time of 60 minutes at $70^{\circ} \mathrm{C}$ with no added 
humidity was found to cause $>3 \log$ reduction in the SARS-COV-2 virus ${ }^{7}$ though the study was not on N95 mask material. Other reports have shown that compared to dry heat, higher humidity (>50\%) required shorter treatment times of $\sim 30$ minutes at $70^{\circ} \mathrm{C}, 11$ similar to previous studies on the influenza virus. ${ }^{26}$ Most of these studies have also shown that respirator performance was not degraded after 5 treatment cycles at $75-85^{\circ} \mathrm{C}$ at $60-90 \%$ relative humidity for 30 minutes. Since longer heating times would be more effective in ensuring adequate decontamination (provided they did not degrade mask fit and filtration performance) we explored a treatment regime of $70^{\circ} \mathrm{C}$ for 60 minutes, the necessary conditions for "dry heat" decontamination, while also providing additional humidity in the oven environment.

\section{Heat based protocol tested on single masks at TIFR}

Experiments were carried out in a laboratory oven with a $45 \mathrm{~cm} \times 45 \mathrm{~cm} \times 40 \mathrm{~cm}$ chamber (Trishul Instruments, Mumbai). Apart from the oven temperature control display, temperature and humidity sensors were taped on the test N95 masks to ensure that the actual mask surface conditions could be monitored (See Fig. 1). For this a temperature and humidity meter (based on a Sensirion SHT-31 T/RH sensor, or EL-USB-2 temperature/humidity logger) were used. For the first trial, a 3M 8822 N95 mask (a common mask being used at TMH) was subjected to 5 heating cycles at a target temperature of $70^{\circ} \mathrm{C}$ for a duration of 60 minutes at the target temperature. The set point was adjusted to achieve a mask surface temperature just above $70^{\circ} \mathrm{C}$. For masks kept directly on the oven rack the surface temperature reached the target temperature within 7-10 minutes. For masks kept inside (an open) paper bag, the mask temperature reached the target temperature in about 1012 minutes time. The temperatures recorded in the 5 cycles was between $70-75^{\circ} \mathrm{C}$. While the temperature of the oven could be easily controlled via a PID controller, no in-built humidity control was available. Given the local laboratory conditions (ambient humidity $75-80 \%$ in Mumbai) the minimum humidity at $70^{\circ} \mathrm{C}$ was $\sim 12-15 \%$. Sheets of tissue paper dosed with tap water were kept on the base of the oven and saturated before use. This increased the humidity of the oven to $25-40 \%$ during the 60 minute period. 


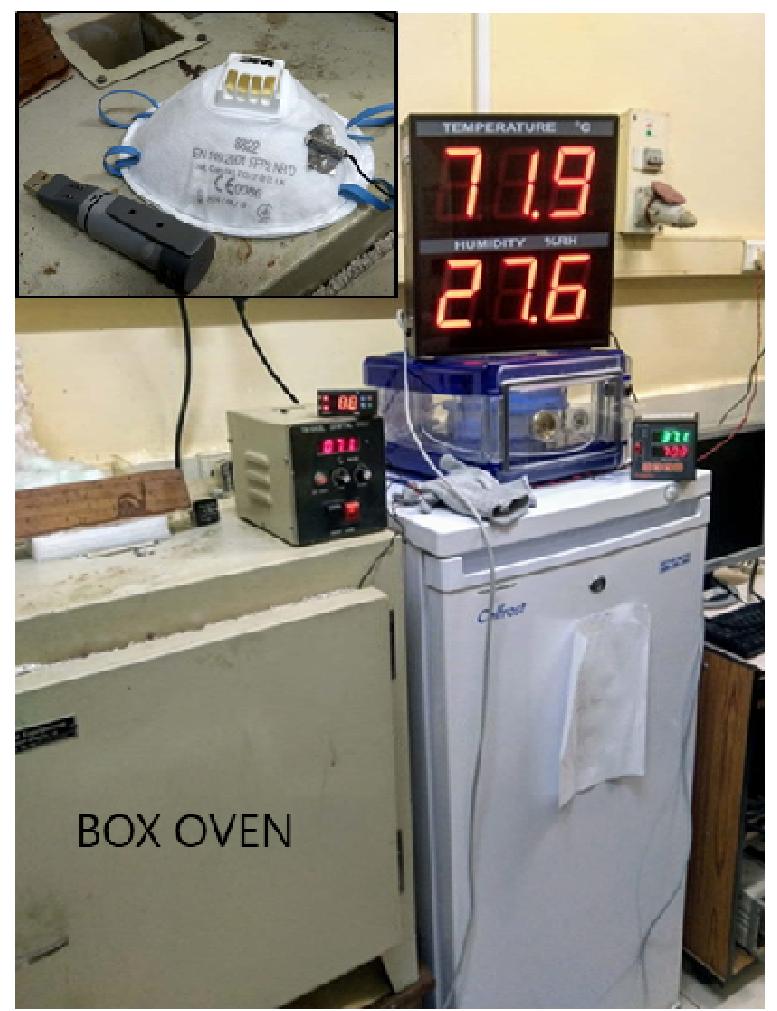

Fig. 1: Box oven used for heating experiments at TIFR. Inset: 3M 8822 mask with the temperature/humidity probe stuck on it with conductive metal tape.

Following each heat treatment cycle the particle filtration efficiency (PFE) for $0.3 \mu \mathrm{m}$ sized particles was measured. Because of the COVID-19 pandemic and consequent lockdown, we did not have access to commercial mask filtration test equipment, and the measurements were performed on a home-built setup to measure the PFE using an air-quality monitor as a particle counter. In our test setup air is sucked through the particle counter using a vacuum pump (at $\sim 10 \mathrm{lpm}$, similar to human breathing rates) and the throughput of $0.3 \mu \mathrm{m}$-sized particles (for N95) measured with and without a mask, and the PFE determined from the ratio of these counts. A stable background of $0.3 \mu \mathrm{m}$ particles was created using normal saline $(0.9 \% \mathrm{NaCl}$ solution) in a nebulizer to make a fine aerosol. Details of the mask filtration test system are available on a GitHub repository. ${ }^{27}$ Since the entire mask was tested, the sides of the mask were taped to the holder to ensure that there was no leakage of particles from the sides. 


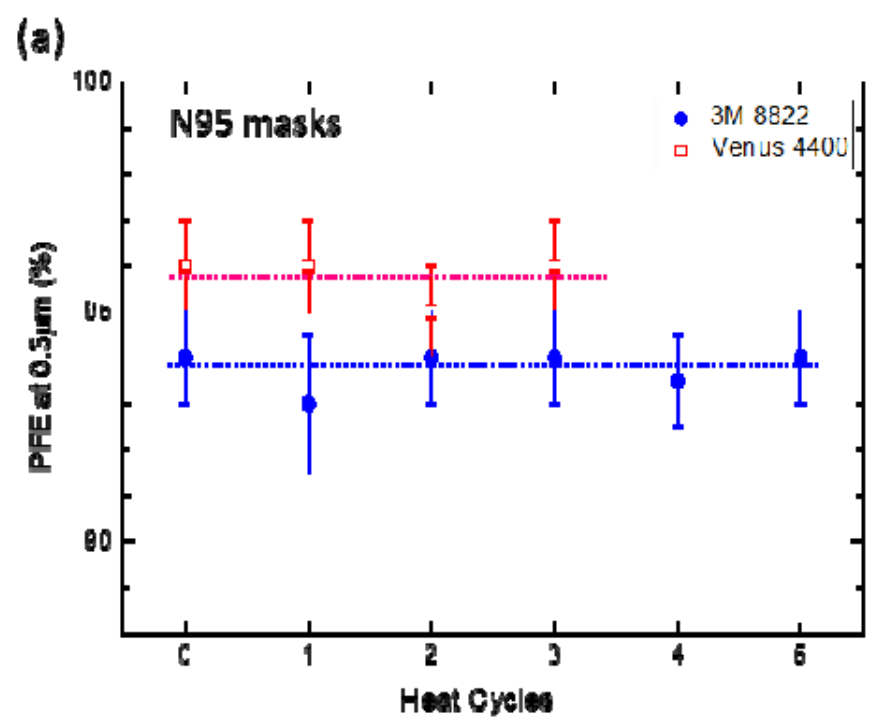

(b)

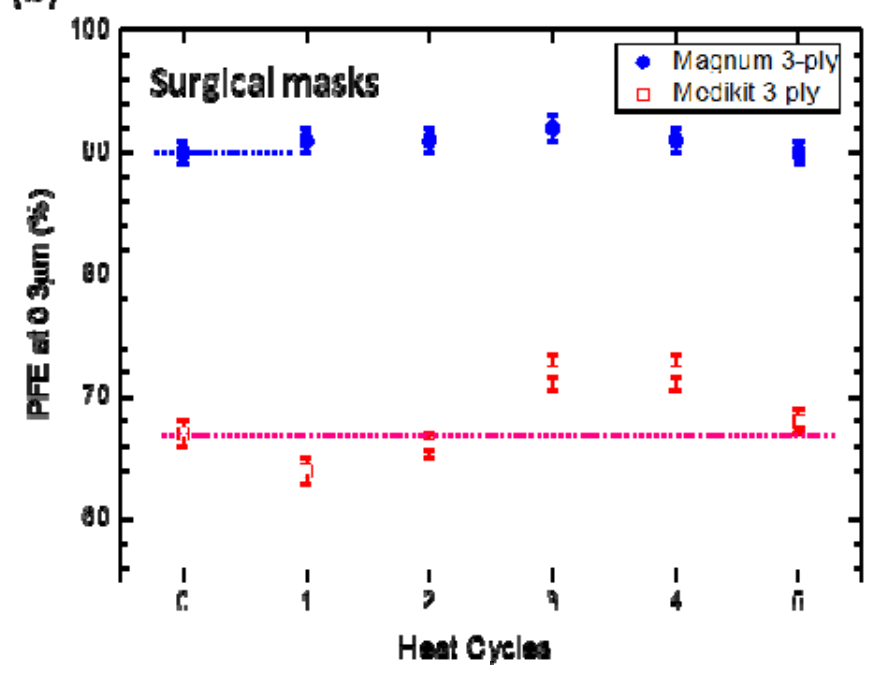

Fig. 2: Particle filtration efficiency values (at $0.3 \mu \mathrm{m}$ size) for different heat treatment cycles for (a) N95 masks and (b) surgical masks. Within the limits of our measurement no degradation in filtration efficiency was seen.

PFE data for the pristine mask and after the 5 heat treatment cycles are shown in Fig. 2(a). We also carried out the same heat treatment for 3 cycles on a Venus 4400 N95 mask. Further, a 5 cycle heat treatment study was also performed on two types of surgical masks commonly available in Indian hospital settings, data are shown in Fig. 2(b). In all cases, we did not observe any change in the filtration efficiency compared to the pristine masks. Additionally other masks commonly used in hospitals in India (Venus 4200, Chinese KN95 masks, Magnum 95001) were also subjected to similar heat treatment cycles with no measureable degradation in filtration efficiency. 
medRxiv preprint doi: https://doi.org/10.1101/2020.09.28.20203067; this version posted September 29, 2020. The copyright holder for this preprint (which was not certified by peer review) is the author/funder, who has granted medRxiv a license to display the preprint in perpetuity.

It is made available under a CC-BY-ND 4.0 International license .

To check if the heating cycles had any effect on the microstructure of the fibers, electron microscopy studies were carried out on the filter layers of the N95 mask. Small samples were punched out of both a pristine and the heat-treated mask, the various layers separated out using a tweezer, and examined in a Zeiss EVO scanning electron microscope. The comparative images of the layers shown in Fig. 3 suggest that there is no change in the microstructure before and after the 5 heat treatment cycles, corroborating the filtration efficiency measurements.
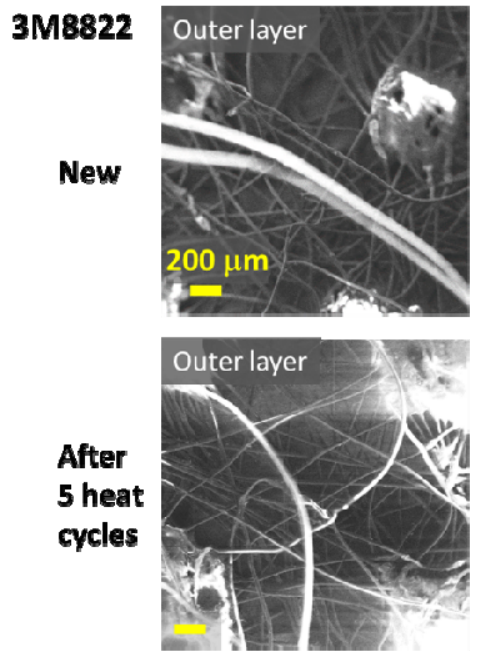
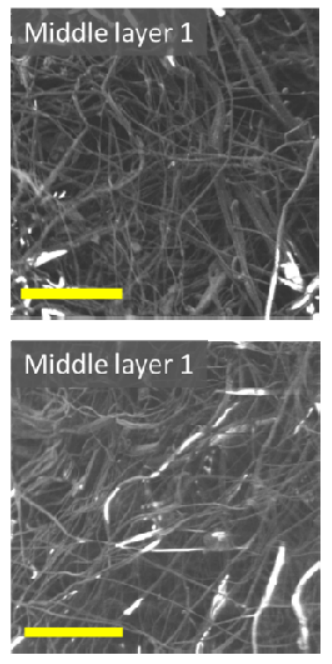
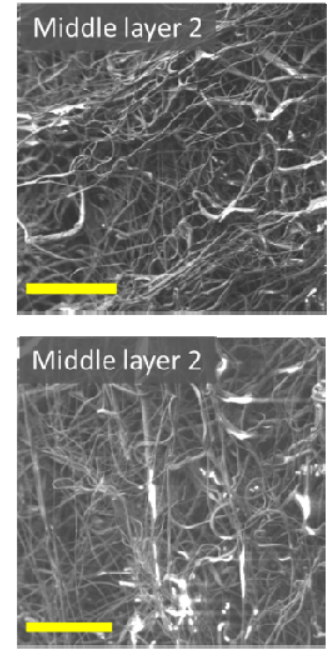
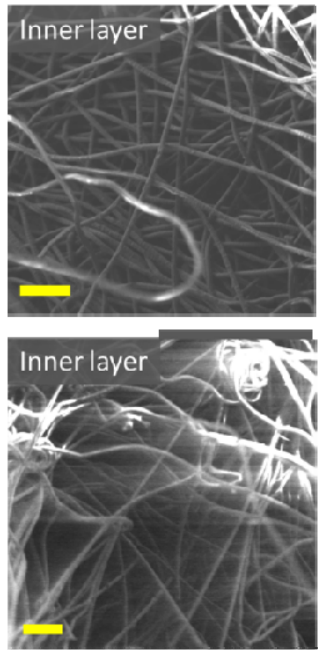

Fig. 3: Scanning electron microscopy images of the different layers of a 3M8822 mask. The top row shows images of a pristine mask, the bottom row is the mask after 5 heating cycles $\left(70^{\circ} \mathrm{C} 1\right.$ hour).

The regular pattern of large white spots in the outer layer are impressions from the thermal calendering process used to make the spun-bond non-woven fabrics. All scale bars are $200 \mu \mathrm{m}$.

\section{Scale up and Implementation at a Pan-Hospital level}

After selection of dry heat method for decontamination, and having tested the structural and functional integrity post decontamination, we were faced with the bigger challenge of scaling the process to cater to a multi-department, large-hospital setting. With more than 2000 N95 respirator users, requiring decontamination in a periodic manner, we developed several practical but innovative approaches to address this problem of scaling while optimally balancing reuse and safety.

An appropriate heat drying cabinet (Axyos Technologies) was identified in the Central Sterilization Services Department (CSSD) of TMH that could maintain the required $\sim 70{ }^{\circ} \mathrm{C}$ temperature uniformly in all parts of the dryer. The dryer has two vertical halves each approximately $180 \mathrm{~cm}$ tall, $60 \mathrm{~cm}$ wide and $90 \mathrm{~cm}$ deep, with grilled racks that can be placed at desired heights. Apart from the in-built temperature displays for the left and right halves of the drying cabinet, two external temperature 
sensors and temperature/ humidity sensors were used to monitor the temperature at various locations in the cabinet. First, the temperature uniformity of the drying cabinet around a $70^{\circ} \mathrm{C}$ setpoint was evaluated. While the uniformity across a single rack was within $\pm 1{ }^{\circ} \mathrm{C}$, there was a greater temperature variation from top to bottom of $\sim 5^{\circ} \mathrm{C}$, as expected due to convective heat flow.

Previous implementations of heat-decontamination for N95 masks, e.g. Anderegg et al. ${ }^{9}$, have suggested keeping masks in individual sealed plastic boxes, each with a small tissue paper with a carefully dosed amount of water using a micropipette, to ensure similar humidity levels in each box. An important difference between this and our work is that we use open-top paper bags ${ }^{*}$ to hold the masks for a decontamination, as opposed to sealed boxes. While this necessarily implies that we cannot ensure that each mask is subject to the exact same conditions of temperature and humidity, we believe our method greatly simplifies the logistics of handling a large number of masks. The use of paper bags serves three extremely important functions: 1 . Individual bags are labelled by users making it easy to trace and return the masks to the respective users; 2 . The CSSD and Decon Team never had to come in direct contact with the N95 masks, minimizing the chance for contamination; and 3. The open top paper bag naturally allowed the mask to "air out" in storage.

To ensure that the N95 masks inside the paper bags reached the target temperature, a set of calibration experiments were carried out. Temperature probes were attached to dummy masks in paper bags, which were kept at various locations in the drying cabinet. Based on these experiments the heating setpoint was kept at $75{ }^{\circ} \mathrm{C}$ to ensure that the mask temperature at any location would be $\geq 70^{\circ} \mathrm{C}$. While each rack could hold 16 paper bags, to ensure adequate airflow a maximum of 12 bags were loaded per rack to allow for adequate airflow. In this configuration a maximum of 96 masks could be loaded for decontamination in one heating cycle. A picture of the drying cabinet with a full load of masks is shown in Fig. 4.

Opening the door of the cabinet to load the entire set of paper bags caused a temperature drop of $\sim 10^{\circ} \mathrm{C}$, and it took $\sim 15$ minutes for the temperature to re-stabilize to the setpoint value. The one hour cycle time was calculated after the temperature had reached a stable value. A wet towel was kept at the bottom of the cabinet before the start of each run, resulting in a humidity level of typically $35 \%$ at the beginning of each run, decreasing to $10-14 \%$ at the end of the run. While the $70^{\circ} \mathrm{C}$ one hour conditions ensured decontamination as per previous dry heat studies, humidity was an additional attempt to increase the efficacy.

\footnotetext{
"These are standard "sickness bags" - paper bags with an internal waterproof coating. The bags were heated to $\sim 90{ }^{\circ} \mathrm{C}$ for 2 hours to ensure that there was no deterioration of the paper bag material.
} 
medRxiv preprint doi: https://doi.org/10.1101/2020.09.28.20203067; this version posted September 29, 2020. The copyright holder for this preprint (which was not certified by peer review) is the author/funder, who has granted medRxiv a license to display the preprint in perpetuity.

It is made available under a CC-BY-ND 4.0 International license .

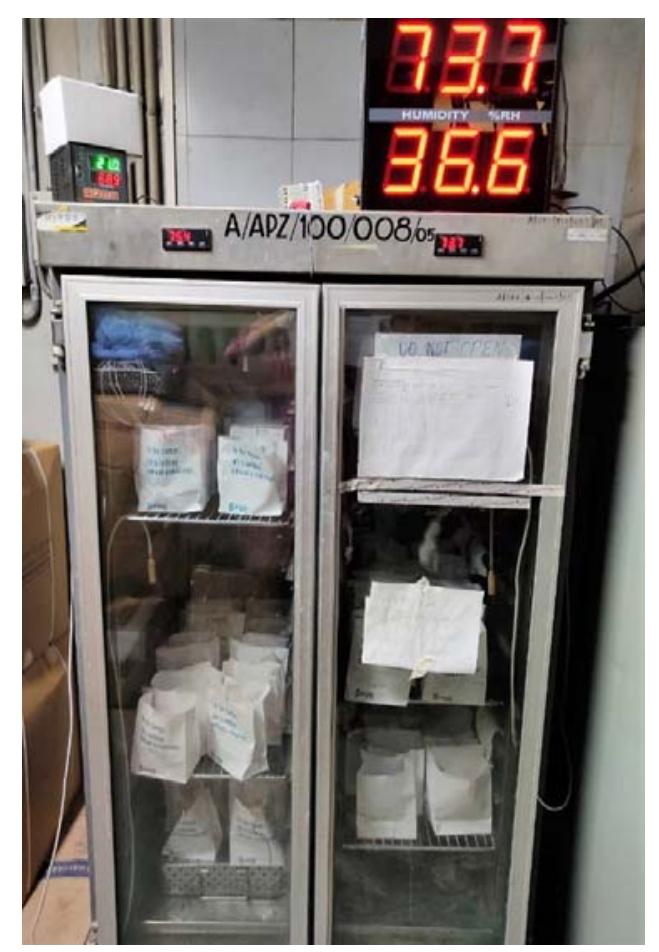

Fig. 4: The Axyos drying cabinet used for the heat-based decontamination process at the hospital, with a load of $N 95$ masks kept in open-top paper bags. 
medRxiv preprint doi: https://doi.org/10.1101/2020.09.28.20203067; this version posted September 29, 2020. The copyright holder for this preprint (which was not certified by peer review) is the author/funder, who has granted medRxiv a license to display the preprint in perpetuity.

It is made available under a CC-BY-ND 4.0 International license.

\section{Logistics of decontamination}

Hospital-wide staff were divided into 65 subunits (departments, disease management groups, surgical, medical, radiation, radiology, nursing, etc.) depending on location of the facility, number of personnel in each subunit and expected requirements for N95 mask decontamination (Table 1). From each of these 65 units, a unit-coordinator was selected to ensure smooth functioning. To ensure optimal utilization of the decontamination facility without compromising on safety, weekday slots were meticuolously planned among the 65 units to prevent overcrowding, ensure safe distancing and smooth flow of deposit/collection of N95 masks from designated locations. Detailed SOPs were put into place with instructions and expected compliance at user level and unitcoordinator level and the decontamination team (Table 2). 
medRxiv preprint doi: https://doi.org/10.1101/2020.09.28.20203067; this version posted September 29, 2020. The copyright holder for this preprint (which was not certified by peer review) is the author/funder, who has granted medRxiv a license to display the preprint in perpetuity.

It is made available under a CC-BY-ND 4.0 International license .

Table 1 - Division of Hospital-wide staff into units and subunits to facilitate even distribution during weekdays and optimal utilization of N95 mask decontamination facility

\begin{tabular}{|c|c|c|c|c|}
\hline Day & Medical Unit & Surgical Unit & Nursing Unit & Admin/Offices \\
\hline \multirow[t]{6}{*}{ Monday } & Occupation Therapy & Neurosurgery & Catheter Care Clinic & Registration Office \\
\hline & Radiation Oncology & Thoracic Surgery & $\begin{array}{l}\text { Adult chemotherapy } \\
\text { Ward }\end{array}$ & $\begin{array}{l}\text { Nutrition } \\
\text { Department }\end{array}$ \\
\hline & General Medicine & Interventional Radiology & Pediatric Ward & Preventive Medicine \\
\hline & Blood Bank & \begin{tabular}{|l} 
Plastic and \\
Reconstructive Surgery
\end{tabular} & $\begin{array}{l}\text { Female General } \\
\text { Ward }\end{array}$ & \\
\hline & & Gynec Surgery & Private Radiology & \\
\hline & & Dental Surgery & Palliative Medicine & \\
\hline \multirow[t]{5}{*}{ Tuesday } & RT (Cobalt) & Head \& Neck (B) & General OPD & Medical Physics \\
\hline & Blood Bank & Head \& Neck (C) & Male Ward & Staff Clinic \\
\hline & Cytology & $\begin{array}{l}\text { Gastrolntestinal Surgery } \\
\text { (C) }\end{array}$ & $\begin{array}{l}\text { Private Ward }-6,7,8 \\
\text { Floors }\end{array}$ & \\
\hline & Pathology & $\begin{array}{l}\text { Bone and Soft Tissue } \\
\text { Surgery }\end{array}$ & Private OT & \\
\hline & & $\begin{array}{l}\text { Gastrolntestinal Surgery } \\
\text { (A) }\end{array}$ & Main OT & \\
\hline \multirow[t]{4}{*}{ Wednesday } & Medical Oncology & $\begin{array}{l}\text { Gastrolntestinal Surgery } \\
\text { (B) }\end{array}$ & Private Day Care & Linen Department \\
\hline & Pediatric Oncology & Breast Surgery & Stoma Clinic & Director's Office \\
\hline & Radiodiagnosis & & Blood Bank & \\
\hline & Adult Hemato-Oncology & & Isolation Ward & \\
\hline \multirow[t]{5}{*}{ Thursday } & General Medicine & Anaesthesia Department & General Day Care & $\begin{array}{l}\text { Education } \\
\text { Department }\end{array}$ \\
\hline & Nuclear Medicine & Urology Surgery & Pediatric Day Care & $\begin{array}{l}\text { Administration } \\
\text { Offices }\end{array}$ \\
\hline & & Pediatric Surgery & Infection Control & Casualty \\
\hline & & & ICU - 1st Floor & \\
\hline & & & $\begin{array}{l}\text { Semi-Private 3rd, 4th } \\
\text { Floor }\end{array}$ & \\
\hline \multirow[t]{4}{*}{ Friday } & $\begin{array}{l}\text { Gastro-enterology } \\
\text { Medicine }\end{array}$ & Head \& Neck (A) & ICU - 2nd Floor & $\begin{array}{l}\text { Nursing } \\
\text { Administration }\end{array}$ \\
\hline & & & Private OPD & $\begin{array}{l}\text { Radiation Medicine } \\
\text { Centre }\end{array}$ \\
\hline & & & Nursing Education & \\
\hline & & & Minor OT & \\
\hline
\end{tabular}


It is made available under a CC-BY-ND 4.0 International license .

Table 2 - SOPs for Individual Mask User, Unit Coordinator and CSSD/Mask Decon Team

\section{Individual Mask User SOPs}

Please ensure the following SOPs are followed by each member of the unit.

1. Identify the N95 masks allocated to you that needs to be decontaminated (already used up to 5 times at 96 hours intervals)

2. Label the given paper bag with your Name, Department and Institute Code Number and put each individual mask into separate paper bag (ONE MASK PER BAG, Do not put more than one mask in one bag)

3. Do not close/staple the bag. Keep the bags open.

4. The paper bags (with the masks in them) will undergo the decontamination procedure with strict adherence to technical SOPs by the Decon Team and the CSSD staff.

5. Collect the decontaminated masks (in paper bags) from your unit-coordinator.

6. After collection of the decontaminated masks - PLEASE label the mask (not the paper bag) with permanent marker. (The same mask can be decontaminated up to 3-5 times

\section{Unit Coordinator SOPS}

1. Please Coordinate within your unit for collecting all N95 masks (each in individual labelled paper bags) requiring decontamination according to the protocol mentioned above.

2. Please coordinate to send the collected masks, by single person (on trolley or in box), to the designated location (Room No. XXX, near CSSD), between 9 AM and 10 AM on the designated day - so as to avoid overcrowding in the area.

3. Please send a single person for collection of sterilized masks at $\mathbf{3}$ PM on the same day for the entire unit, from the same designated room. He/She can then distribute to individual unit members.

\section{CSSD and Mask Decon Team SOPs (simplified)}

1. A day prior, notify and remind subunits to deposit N95 masks to be decontaminated between 9 and 10 AM

2. Prime the Heat Dryer Oven at $8 \mathrm{AM}$ - check temperature, probes, space and electric supply

3. At the time of collection, document the unit, department, names of mask users, number of masks deposited by each coordinator

4. After collection of paper bags (with mask in them), take them to the Heat Dryer Oven and place on shelves with adequate air flow guaranteed between individual masks

5. Place temperature probes on maximum shelves possible to record temperature on each shelf

6. Close and ensure the seal of doors of the oven. Wait till temperature across all probes reaches $>70^{\circ} \mathrm{C}$. Note the time and keep the doors sealed for at least 60 minutes

7. After the cycle, note the time and temperature and take out paper bags (with masks in them) and take them to the designated point for recollection by the unit coordinator

8. DO NOT TOUCH the masks directly at any point. Handle the paper bags NOT the masks

9. Handover to respective unit coordinators between 3 and 4 PM

\section{General Instructions}

1. The decontamination process is designed to kill viruses and most bacteria NOT fungal spores.

2. Filtration and structural integrity of $3 \mathrm{M}$, Venus and Filtra masks have been tested post heat decontamination method in-house. Rest of the makes have not been tested but literature suggests other N95 masks can also be decontaminated using dry heat methods.

3. Do not submit structurally damaged masks for decontamination.

4. If the masks show signs of fungal patches (stains) do not submit for decontamination. Please discard them and get new masks.

5. Do not apply any solutions or reagents to the masks to be decontaminated. It may compromise the decontamination process as well as damage the masks.

6. Multiple usage of masks by itself induces a peculiar smell. Decontamination process does not augment or eliminate the smell. 
After setting up the above logistics, the decontamination facility of TMH became functional on May 28, 2020. Till Sept 22, 20208193 N95 masks of $\sim 1400$ individual users, have undergone decontamination and are in reuse. Apart from the monetary cost savings, this endeavour has demonstrated the feasibility of such an exercise on a large-scale pan-hospital setting. The most common reason for rejection of user-deposited masks before decontamination was visible stains and fungal mold on the fabric. Physical distortion of structure was seen in 8 N95 masks after decontamination process. The damage appeared due to solvent treatment of mask before heat treatment but could not be proven.

\section{Conclusions}

We have developed an easy and scalable method of heat-based N95 FFR decontamination and demonstrated its deployment in a large hospital setting. Our method of subjecting the masks to target heating conditions of temperature of $70^{\circ} \mathrm{C}$ for a duration of 1 hour using a hot drying cabinet found in most hospitals can be replicated widely with no additional expenditure. Except for viricidal experiments (for which we have depended on established literature), filtration and structural integrity checks were done in-house. A key to successful utilization of such a decontamination facility is the optimization of the logistics of implementation across the hospital, from developing SOPs for individual users and decontamination system operators to scheduling appropriate timeslots for various sections. While these decontamination procedures were developed out of sheer necessity in crisis periods of N95 mask shortages, we believe that such re-use processes, which significantly reduce medical waste generated, may cause a shift to a more environmentallyresponsible usage of N95 masks even under normal circumstances of abundant availability.

\section{Conflicts of Interest}

The authors declare no conflict of interests.

\section{Acknowledgements}

We thank Emroj Hossain and Mahesh Gokhale for technical assistance and several useful discussions, and acknowledge the support of the TIFR electron microscopy group for SEM imaging. The work was supported through internal grants from TIFR and TMH. 


\section{References}

${ }^{1}$ https://www.who.int/emergencies/diseases/novel-coronavirus-2019/advice-for-public/when-and-how-to-
use-masks
${ }^{2}$ A curated summary of decontamination techniques is available at http://n95decon.org
${ }^{3}$ Disinfection of Filtering Facepiece Respirators, Release $2.3 \mathrm{M}(2020)$
https://multimedia.3m.com/mws/media/18165760/disinfection-of-disposable-respirators-
technicalbulletin.pdf
${ }^{4}$ Liao, L., Xiao, W., Zhao, M., Yu, X., Wang, H., Wang, Q., Chu, S., Cui, Y. (2020). Can N95 respirators be reused after disinfection? And for how many times? medRxiv. Advance online publication. https://doi.org/10.1101/2020.04.01.20050443

${ }^{5}$ U.S. Department of Health and Human Services, Centers for Disease Control and Prevention (CDC). (2020, April 9). Decontamination and Reuse of Filtering Facepiece Respirators. https://www.cdc.gov/coronavirus/2019-ncov/hcp/ppe-strategy/decontamination-reuse-respirators.html ${ }^{6}$ Viscusi, D. J., Bergman, M. S., Eimer, B. C., \& Shaffer, R. E. (2009). Evaluation of Five Decontamination Methods for Filtering Facepiece Respirators. The Annals of Occupational Hygiene, 53(8), 815-827. https://doi.org/10.1093/annhyg/mep070

${ }^{7}$ Fischer, R. J., Morris, D. H., van Doremalen, N., Sarchette, S., Matson, M. J., Bushmaker, T., Yinda, C. K., Seifert, S. N., Gamble, A., Williamson, B. N., Judson, S. D., de Wit, E., Lloyd-Smith, J. O., \& Munster, V. J. (2020). Assessment of N95 respirator decontamination and re-use for SARS-CoV-2. medRxiv.

https://www.medrxiv.org/content/10.1101/2020.04.11.20062018v2

${ }^{8}$ Price, A. Cui, Y., Liao, L., Xiao, W., Yu, X., Wang, H., Zhao, M., Wang, Q., Chu, S., \& Chu, L. (2020). Is the fit of N95 facial masks effected by disinfection? A study of heat and UV disinfection methods using the OSHA protocol fit test. medRxiv. Advance online publication. https://doi.org/10.1101/2020.04.14.20062810 ${ }_{9}^{9}$ Anderegg, L., Meisenhelder, C., Ngooi, C. O., Liao, L., Chu, S., Cui, Y., \& Doyle, J.M. (2020). A Scalable Method of Applying Heat and Humidity for Decontamination of N95 Respirators During the COVID-19 Crisis. PLOS ONE 15(7): e0234851. https://doi.org/10.1371/journal.pone.0234851

${ }^{10}$ Pastorino, B., Touret, F., Gilles, M., de Lamballerie, X., \& Charrel, R. N. (2020). Evaluation of heating and chemical protocols for inactivating SARS-CoV-2. bioRxiv. Advance online publication. https://doi.org/10.1101/2020.04.11.036855

${ }^{11}$ van Straten, B., de Man, P., van den Dobbelsteen, J., Koeleman, H., van der Eijk, A., \& Horeman, T. (2020). Sterilization of disposable face masks by means of standa rdized dry and steam sterilization processes; an alternative in the fight against mask shortages due to COVID-19, Journal of Hospital Infection. https://doi.org/10.1016/j.jhin.2020.04.001

${ }^{12}$ Massey, T., Paik, S., Fuhrer, K., Bora, M., Haque, R., Baxmusa, S. H. (2020). Quantitative form and fit of N95 filtering facepiece respirators are retained after dry and humid heat treatments for coronavirus deactivation. medRxiv. Advance online publication. https://doi.org/10.1101/2020.04.15.20065755

${ }^{13}$ Kumar, A., Kasloff, S. B., Leung, A., Cutts, T., Strong, J. E., Hills, K., Vazquez-Grande, G., Rush, B., Lother, S., Zarychanski, R., \& Krishnan, J. (2020). N95 Mask Decontamination using Standard Hospital Sterilization Technologies. medRxiv. https://doi.org/10.1101/2020.04.05.20049346

${ }^{14}$ Oh, C., Araud, E., Puthussery, J.V., Bai, H., Clark, G.G., Wang, L., Verma, V., Nguyen T.H., (2020) Dry Heat as a Decontamination Method for N95 Respirator Reuse, ACS Envir. Sci. Lett., in press, https://dx.doi.org/10.1021/acs.estlett.0c00534

${ }^{15}$ Grinshpun S.A, Yermakov M, Khodoun M. Autoclave sterilization and ethanol treatment of re-used surgical masks and N95 respirators during COVID-19: impact on their performance and integrity. J Hosp Infect. 2020 Aug;105(4):608-614. doi: 10.1016/j.jhin.2020.06.030.

${ }^{16}$ Salter, W. B., Kinney, K., Wallace, W. H., Lumley, A. E., Heimbuch, B. K., \& Wander, J. D. (2010). Analysis of residual chemicals on filtering facepiece respirators after decontamination. Journal of Occupational and Environmental Hygiene, 7 (8), 437-445

17 NPPTL Evaluation of Decontaminated N95 Respirators, ClorDiSys Minidox-M. (2020) National Institute for Occupational Safety and Health. (Internet)

https://www.cdc.gov/niosh/npptl/respirators/testing/results/Decon_003_Redacted -508.pdf 
medRxiv preprint doi: https://doi.org/10.1101/2020.09.28.20203067; this version posted September 29, 2020. The copyright holder for this preprint (which was not certified by peer review) is the author/funder, who has granted medRxiv a license to display the preprint in perpetuity.

It is made available under a CC-BY-ND 4.0 International license .

${ }^{18}$ Chin, A. W. H., Chu, J. T. S., Perera, M. R. A., Hui, K. P. Y., Yen, H.-L., Chan, M. C. W., Peiris, M., \& Poon, L. L. M. (2020). Stability of SARS-CoV-2 in different environmental conditions. Lancet Microbe, in press. https://doi.org/10.1016/S2666-5247(20)30003-3

${ }^{19}$ van Doremalen, N., Bushmaker, T., Morris, D. H., Holbrook, M. G., Gamble, A., Williamson, B. N., Tamin, A., Harcourt, J. L., Thornburg, N. J., Gerber, S. I., Lloyd-Smith, J. O., Wit, E. de, \& Munster, V. J. (2020, March 17). Aerosol and Surface Stability of SARS-CoV-2 as Compared with SARS-CoV-1 [Letter]. In New England Journal of Medicine (world). Massachusetts Medical Society. https://doi.org/10.1056/NEJMc2004973

${ }^{20}$ Bergman, M. S., Viscusi, D. J., Zhuang, Z., Palmiero, A. J., Powell, J. B., \& Shaffer, R. E. (2012). Impact of multiple consecutive donnings on filtering facepiece respirator fit. American Journal of Infection Control, 40(4), 375-380. https://doi.org/10.1016/j.ajic.2011.05.003

${ }^{21}$ Czubryt MP, Stecy T, Popke E, Aitken R, Jabusch K, Pound R, Lawes P, Ramjiawan B, Pierce GN, (2020) N95 Mask Reuse in a Major Urban Hospital - COVID-19 Response Process and Procedure, Journal of Hospital Infection, (in press) https://doi.org/10.1016/j.jhin.2020.07.035.

${ }^{22}$ Pramesh C.S., Badwe R.A., Cancer Management in India during Covid-19, N Engl J Med 2020; $382: e 61$ https://doi.org/10.1056/NEJMc2011595

${ }^{23}$ Hossain, E., Bhadra, S., Jain, H., Das, S., Bhattacharya, A., Ghosh, S. Levine, D. (2020) Recharging and rejuvenation of decontaminated N95 masks, Phys of Fluids 32, 093304, https://doi.org/10.1063/5.0023940

${ }^{24}$ Battelle (2020). The Battelle Decontamination System, an HPV system for decontaminating N95 respirators. https://www. battelle.org/inb/battelle-critical-care-decontamination-system-for-covid19

${ }^{25}$ Russo R, Levine C, Veilleux C, Peixoto B, McCormick-Ell J, Block T, Gresko A, Delmas G, Chitale P, Frees A, Ruiz A, Alland D. Decontaminating N95 respirators during the Covid-19 pandemic: simple and practical approaches to increase decontamination capacity, speed, safety and ease of use. medRxiv. 2020 Aug 21:2020.08.17.20177022. doi: 10.1101/2020.08.17.20177022.

${ }^{26}$ McDevitt, J., Rudnick, S., First, M., \& Spengler J. (2010). Role of Absolute Humidity in the Inactivation of Influenza Viruses on Stainless Steel Surfaces at Elevated Temperatures. Applied and Environmental

Microbiology, 76 (12), 3943-3947. https://doi.org/10.1128/AEM.02674-09

27 https://github.com/shescitech/TIFR_Mask_Efficiency 
medRxiv preprint doi: https://doi.org/10.1101/2020.09.28.20203067; this version posted September 29, 2020. The copyright holder for this preprint (which was not certified by peer review) is the author/funder, who has granted medRxiv a license to display the preprint in perpetuity.

It is made available under a CC-BY-ND 4.0 International license .

Fig. 1: Box oven used for heating experiments at TIFR. Inset: $3 M 8822$ mask with the temperature/humidity probe stuck on it with conductive metal tape.

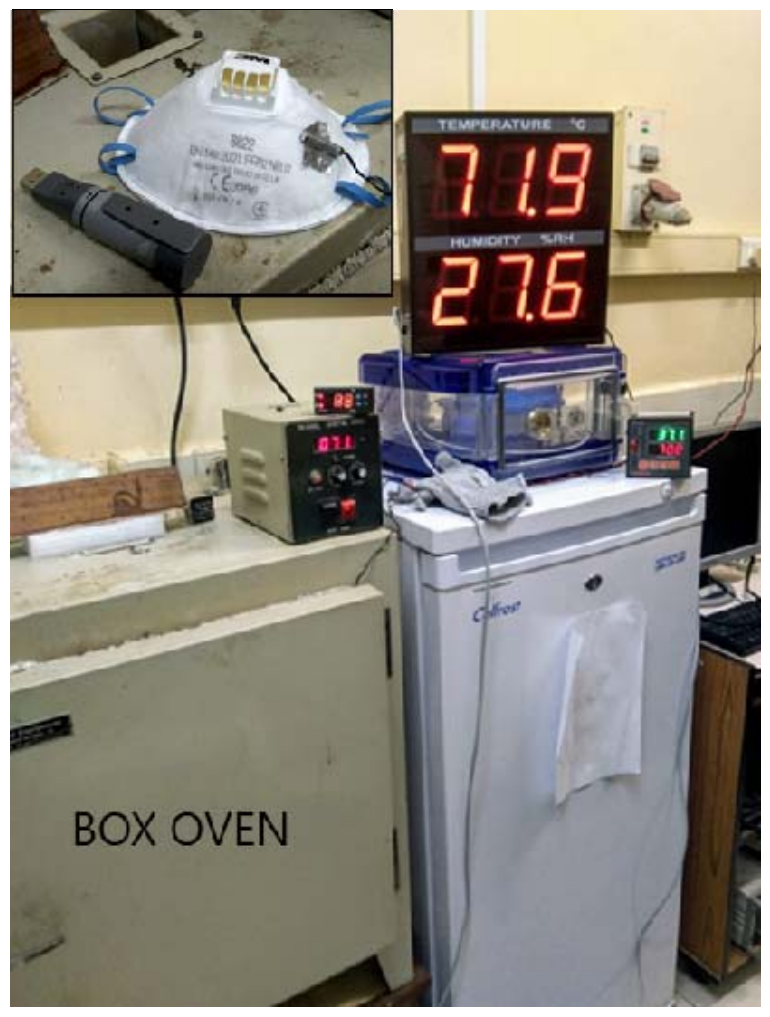


medRxiv preprint doi: https://doi.org/10.1101/2020.09.28.20203067; this version posted September 29, 2020. The copyright holder for this preprint (which was not certified by peer review) is the author/funder, who has granted medRxiv a license to display the preprint in perpetuity.

It is made available under a CC-BY-ND 4.0 International license.

Fig. 2: Particle filtration efficiency values (at $0.3 \mu \mathrm{m}$ size) for different heat treatment cycles for (a) N95 masks and (b) surgical masks. Within the limits of our measurement no degradation in filtration efficiency was seen.

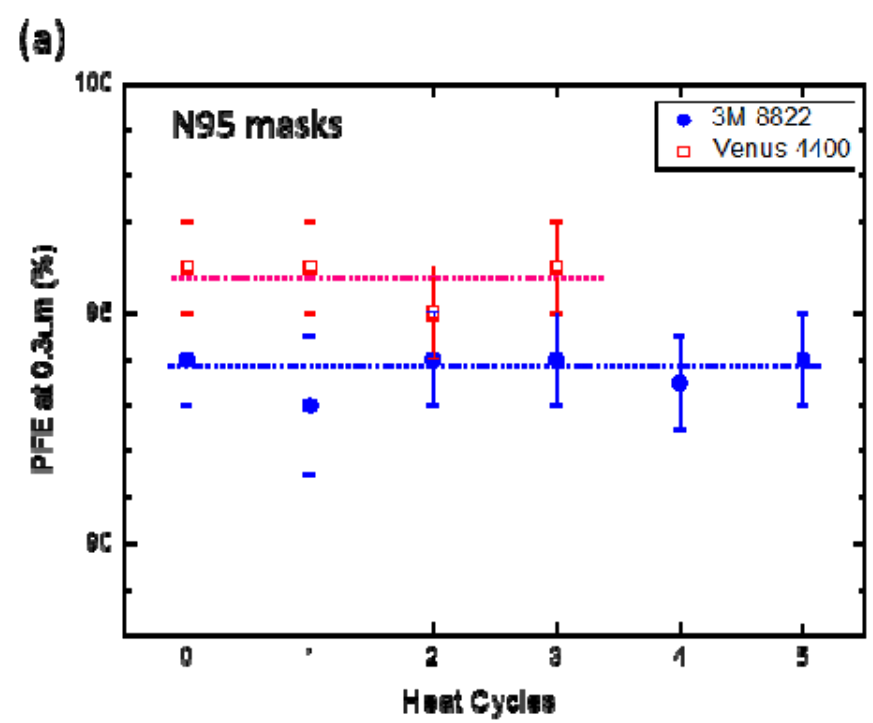

(b)

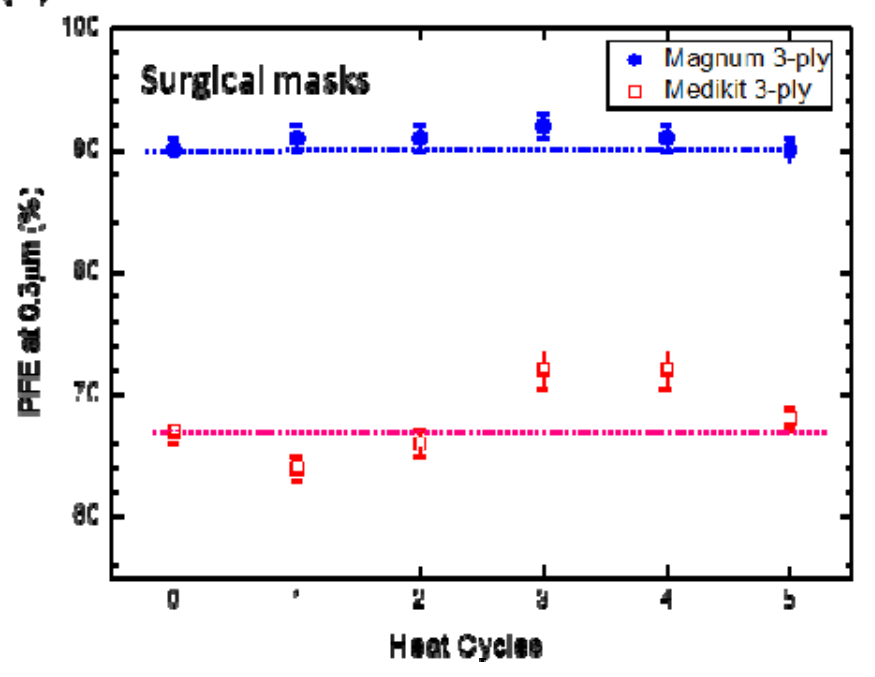


medRxiv preprint doi: https://doi.org/10.1101/2020.09.28.20203067; this version posted September 29, 2020. The copyright holder for this preprint (which was not certified by peer review) is the author/funder, who has granted medRxiv a license to display the preprint in perpetuity.

It is made available under a CC-BY-ND 4.0 International license .

Fig. 3: Scanning electron microscopy images of the different layers of a $3 M 8822$ mask. The top row shows images of a pristine mask, the bottom row is the mask after 5 heating cycles $\left(70^{\circ} \mathrm{C} 1\right.$ hour).

The regular pattern of large white spots in the outer layer are impressions from the thermal calendering process used to make the spun-bond non-woven fabrics. All scale bars are $200 \mu \mathrm{m}$.
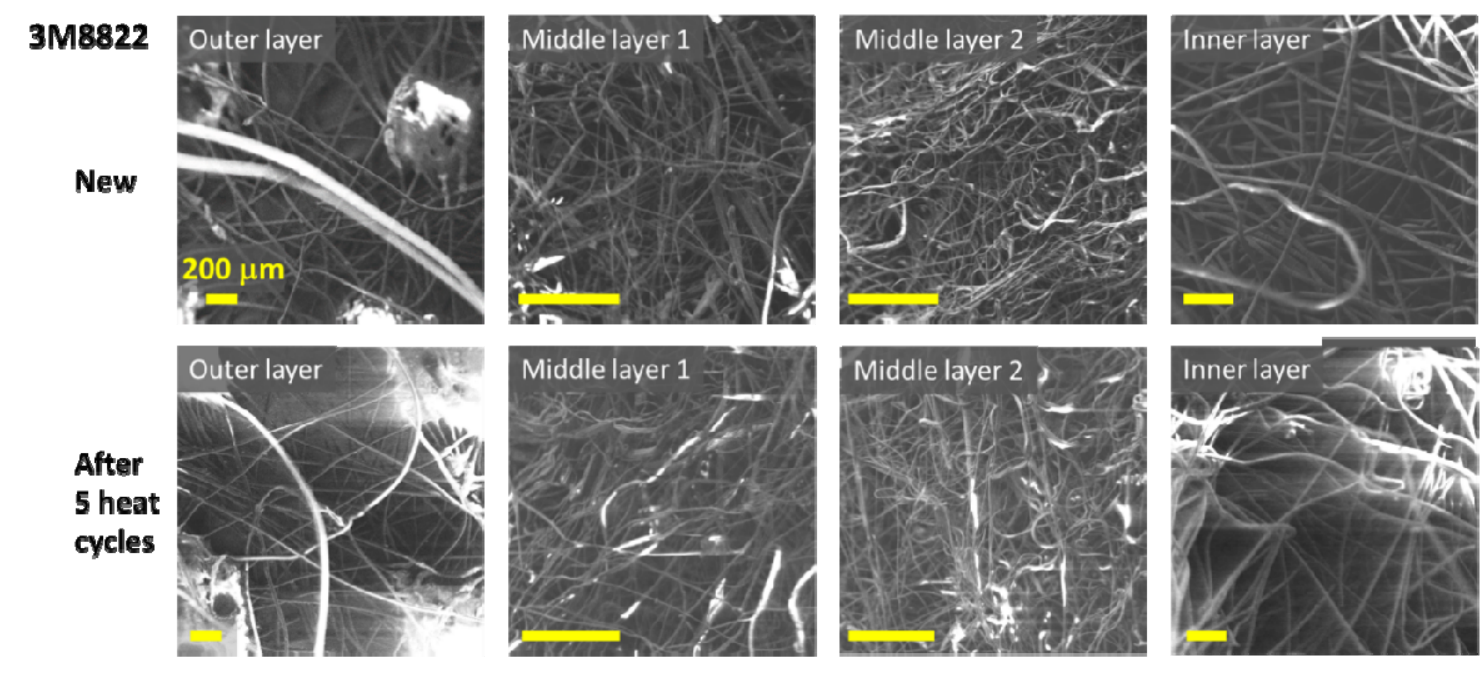
medRxiv preprint doi: https://doi.org/10.1101/2020.09.28.20203067; this version posted September 29, 2020. The copyright holder for this preprint (which was not certified by peer review) is the author/funder, who has granted medRxiv a license to display the preprint in perpetuity.

It is made available under a CC-BY-ND 4.0 International license .

Fig. 4: The Axyos drying cabinet used for the heat-based decontamination process at the hospital, with a load of $N 95$ masks kept in open-top paper bags.

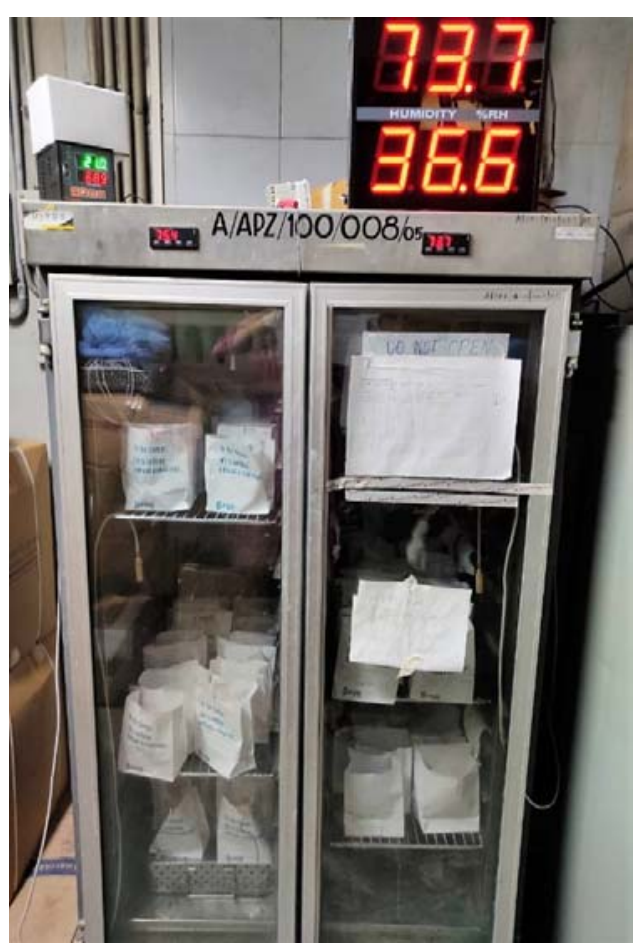

